\title{
Phosphorus Mobility in a Soil with Long Term Manure Application
}

\author{
Abimbola Ojekami \\ Department of Soil Science, University of Manitoba \\ Winnipeg, R3T 2N2, Canada \\ E-mail: researchinmanitoba2005@yahoo.com \\ Dupe Ige \\ Department of Soil Science, University of Manitoba \\ Winnipeg, R3T 2N2, Canada
}

Tel: 1-204-480-1816 E-mail: ige@cc.umanitoba.ca

\author{
Xiying Hao \\ Agriculture and Agri-Food Canada,
} 5403, 1st Avenue South, Lethbridge, Alberta, T1J 4B1, Canada

Tel: 1-403-317-2279 E-mail: HaoXy@AGR.GC.CA

Oluwole Akinremi (Corresponding author)

Department of Soil Science, University of Manitoba

Winnipeg, R3T 2N2, Canada

Tel: 1-204-474-6055Ｅ-mail: akinremi@cc.umanitoba.ca

Received: July 21, 2010 Accepted: August 3, 2010 doi:10.5539/jas.v3n3p25

The funding for this study was provided by the Faculty of Graduate Studies at University of Manitoba and Syngenta Seed and Crop Protection

\begin{abstract}
The objective of this experiment was to determine the movement of different forms of phosphorus (P) in a clay loam soil with 33 years of manure application at the rate of $0,30,60$ and $120 \mathrm{Mg} \mathrm{ha}^{-1} \mathrm{yr}^{-1}$. Soil samples were taken from 3 soil layers and subjected to leaching in packed soil column. Leachate was analyzed for total $\left(\mathrm{P}_{t}\right)$, inorganic $\left(\mathrm{P}_{\mathrm{i}}\right)$ and organic $\mathrm{P}\left(\mathrm{P}_{\mathrm{o}}\right)$. Inorganic $\mathrm{P}$ accounted for about $70 \%$ of leachate $\mathrm{P}_{\mathrm{t}}$. About $50 \%$ of $\mathrm{P}_{\mathrm{t}}$ in leachate was lost within the first 5 pore-volume (PV). While $2 \%$ of soil total $\mathrm{P}$ was lost in $20 \mathrm{PV}$ of leachate from the control soil, 5-7\% was lost from the manure amended soil. The amount of P lost in the leachate increased with the rate of manure application but decreased with soil depth. This column leaching study showed that $\mathrm{P}$ could be lost through leaching especially at high rate of manure application. Irrigation activity enhanced in situ movement of $\mathrm{P}$ down the soil profile.

Keywords: Column leaching, Leachate, manure, Phosphorus movement, Phosphorus, Inorganic phosphorus, Organic phosphorus, Phosphorus leaching

\section{Introduction}

Land application is the most economical way of using animal manures. Continuous application of manure to meet $\mathrm{N}$ requirements, as is currently practiced on the Canadian prairies, will lead to $\mathrm{P}$ accumulation in the soil (Whalen and Chang, 2001). High amounts of phosphorus, especially in soils with long term manure application, pose a high risk of loss to adjacent water bodies (Chang et al., 2005), and this may have a detrimental impact on water quality.
\end{abstract}


Surface runoff is generally regarded as the main pathway for the loss of $\mathrm{P}$ from the soil as $\mathrm{P}$ has been classified as relatively immobile within the soil (Sims et al., 1998). This is because P is known to strongly interact with both organic and inorganic components of the soil resulting in low soil solution P with reduced risk of loss by leaching. Phosphorus can be retained in the soil by sorption (Castro and Torrent, 1998) and by interaction with soil $\mathrm{Ca}, \mathrm{Mg}, \mathrm{Fe}$ and $\mathrm{Al}$ to form insoluble $\mathrm{P}$ compounds (Akinremi and Cho, 1991; Olatuyi et al., 2009). Based on these interactions and the possibility for these retention mechanisms to be operative in the subsoil, $\mathrm{P}$ leaching from the soil profile is generally considered minimal.

Results from recent literature have shown that $\mathrm{P}$ leaching is possible under a wide range of conditions. For example, Graetz and Nair (1995) reported rapid downward movement of P in very sandy soil of Florida. Sims et al. (1998) and Chardon and van Faassen (1999) demonstrated the leaching of $\mathrm{P}$ in the soil profile of sandy and well-structured soils, respectively. Djodjic et al. (1999) reported that more P was leached in a clay soil column compared to a sandy soil column due to preferential flow through the soil macropores. The possibility for $\mathrm{P}$ movement and the magnitude of P leaching in Canadian soils with long term manure application has not been thoroughly studied.

Manure application can modify several soil properties some of which have direct and indirect effect on the ability of the soil to retain P against leaching (Whalen et al., 2000). Whalen et al. (2000) reported that manure-amended acid soils had significantly higher $\mathrm{pH}$ than unamended soils which was attributed to $\mathrm{pH}$ buffering by bicarbonates and organic acids in cattle manure. The solubility of $\mathrm{P}$ is known to be strongly influenced by soil $\mathrm{pH}$. The addition of manure and other organic amendments has been shown to influence the ability of soils to retain P. Both positive (Borling et al., 2001) and negative (Daly et. al., 2001) impacts have been reported in the literature. The mechanisms responsible for the reduction in P retention include the saturation of $\mathrm{P}$ sorption sites by the added manure P (Sui and Thompson, 2000). The higher the degree of P saturation the greater is the release of $\mathrm{P}$ to the soil solution (Zhou and $\mathrm{Li}, 2001$ ). Organic acids that are produced by manure addition compete with $\mathrm{P}$ for sorption sites thereby reducing P retention (Iyamuremye et al., 1996). On the other hand, the addition of manure is accompanied by addition of cations that can increase P retention (Borling et al., 2001). An increase in P sorption may also occur as a result of inhibition of crystallization of amorphous $\mathrm{Fe}$ and Al oxides by organic acids, making these oxides available to sorb P (Borggaard et al., 1990).

In order to better understand how P moves into subsurface horizons, further studies have been conducted to examine the forms of $\mathrm{P}$ that move within the soil. Turner and Haygarth (2000) examined the forms of P in leachate samples from grassland soils and confirmed that inorganic P constituted the majority (62 to $71 \%$ ) of leached $\mathrm{P}$ from different soil types. They also reported that the proportion of organic $\mathrm{P}$ increased during the spring possibly reflecting turnover from microbial transformation of organic P. Other studies have also confirmed the mobility of inorganic forms of $\mathrm{P}$ (Heckrath et al., 1995). In a recent column study, Idowu et al. (2008) concluded that the type of manure influenced the form of $\mathrm{P}$ that moved in the soil following surface application of different organic amendments. They reported that a greater proportion of total $\mathrm{P}$ in the leachate was lost as inorganic $\mathrm{P}$ with hog manure but as much as $63 \%$ of total $\mathrm{P}$ was in the organic form with beef cattle manure. These results suggest that the risk of loss of $\mathrm{P}$ in the organic form is high with fresh beef cattle manure. Whether or not this translates into significant loss of organic $\mathrm{P}$ in soils with long term beef cattle manure addition is unknown. The loss of organic $\mathrm{P}$ has significant environmental implication as there are fewer retention sites for organic P compared to inorganic P in the subsoils (Anderson and Magdoff, 2005).

Therefore, the objective of this study was to examine the impact of rates of manure application on the rate of $\mathrm{P}$ movement in a manured soil through miscible displacement. Column leaching of the clay loam soil with 33 years of manure application was conducted to identify the forms of P i.e. organic or inorganic, that was moved and to determine the relative rate of movement of the two forms of $\mathrm{P}$. The contributions of the different $\mathrm{P}$ fractions to $\mathrm{P}$ leaching were also evaluated.

\section{Materials and Methods}

The soil samples used for this study were collected from a research site at the Agriculture and Agri-Food Canada Research Centre in Lethbridge, Alberta, Canada. The long-term manure study was initiated in 1973, to determine the effects of repeated annual application of cattle feedlot manure on the productivity of non-irrigated and irrigated soils. Solid cattle feedlot manure was applied at the rate of $0,30,60$ and $90 \mathrm{Mg} \mathrm{ha}^{-1} \mathrm{yr}^{-1}$ (wet weight) to a non-irrigated soil and $0,60,120$ and $180 \mathrm{Mg} \mathrm{ha}^{-1} \mathrm{yr}^{-1}$ (wet weight) to irrigated plots in a split-plot design and incorporated annually in the fall after harvest. This rate of application was approximately equivalent to 0,134 , 268, and $402 \mathrm{~kg} \mathrm{Pha}^{-1}$ (dry wt.) in nonirrigated soils, and 0, 268, 536, and $804 \mathrm{~kg} \mathrm{Pha}^{-1}$ (dry wt.) in irrigated soils. The soil is a calcareous Orthic Dark Brown Chernozemic clay loam (Haplic Kastanozen in FAO Soil 
Classification System). The details of the experiment are given by Sommerfeldt and Chang (1985) and Hao et al. (2004). Table 1 showed the initial properties of the soil and the average characteristics of the manure applied over the first 30 years.

Soil samples were collected at 3 depths $(0-15,15-30$ and $30-60 \mathrm{~cm})$ from four treatment plots namely 0,60 and $120 \mathrm{Mg} \mathrm{ha}^{-1} \mathrm{yr}^{-1}$ irrigated plots and $60 \mathrm{Mg} \mathrm{ha}^{-1} \mathrm{yr}^{-1}$ non-irrigated plot in the fall of 2006. Soil samples were air-dried, ground to size $<2 \mathrm{~mm}$, and stored for further analysis.

\subsection{Column Leaching of Phosphorus}

A miscible displacement experiment was conducted using a soil column to examine the mobility of organic and inorganic forms of $\mathrm{P}$ as affected by different rate of manure application, soil depth and irrigation. The column study was based on the modification of the miscible displacement technique described by Cho et al. (1970). A cylindrical column of internal diameter of $5.0 \mathrm{~cm}$ and length of $15 \mathrm{~cm}$ was sealed at the base with a perforated acrylic circular disc of similar diameter. The bottom of the cylindrical acrylic tube was attached to a funnel to serve as a drainage port. The circular disc was covered with a Whatman \#50 filter paper to contain the soil. The tip of the funnel was plugged using a rubber stopper to allow for wet packing of the soil. The column experiment was carried out in 2 replicates.

The soil sample was packed into the column using a wet packing technique described by Oliviera et al. (1996) to attain a bulk density of $0.8 \mathrm{Mg} \mathrm{m}^{-3}$. Briefly, the cylindrical column was $75 \%$ filled with $0.01 \mathrm{M}$ calcium chloride, and the soil sample was carefully added to the column to prevent preferential settling. The top of the soil was covered with another Whatman \#50 filter paper to prevent soil dispersion when electrolyte stream is introduced. The height of the packed soil column was approximately $12 \mathrm{~cm}$ and the mass of soil packed into the column was $189 \mathrm{~g}$.

The cylindrical column was covered with a rubber stopper fitted with an inlet valve from which continuous flow of $0.01 \mathrm{M}$ calcium chloride electrolyte was introduced by a variable speed Masterflex pump (Cole-Parmer Instrument Co., IL, USA). Pore volume was calculated as:

$$
P V=V_{t}\left(1-\rho_{b} / \rho_{s}\right)
$$

where PV is the pore volume, $V_{t}$ is the volume of the column occupied by the soil $\left(\mathrm{cm}^{3}\right), \rho_{b}$ is the bulk density and $\rho_{\mathrm{s}}$ is the particle density (assumed to be $2.65 \mathrm{~g} \mathrm{~cm}^{-3}$ for mineral soils). For this study, a pore volume was estimated to be $165 \mathrm{~cm}^{3}$. Figure 1 showed the picture of the experimental set up of the column leaching study.

Leachate sample was collected using a fractional collector (Model 560; Instrumentation Specialties Co., Superior Lincoln, NB, USA). The flow rate of electrolyte solution into the soil columns was manually controlled to maintain a constant head within replicate. A total of $20 \mathrm{PV}$ of leachate sample was collected at $0.5 \mathrm{PV}$ intervals.

Leachate samples were analyzed for $\mathrm{P}_{\mathrm{t}}$ using ICP-AES (Varian Incorporation, Palo Alto, CA, USA) and $\mathrm{P}_{\mathrm{i}}$ was determined by Murphy and Riley (1962) method using Ultrospec 3100 pro UV/Visible spectrophotometer (Biochrom Ltd, Cambridge, UK). Organic $\mathrm{P}$ was determined as the difference between the $\mathrm{P}_{\mathrm{t}}$ and $\mathrm{P}_{\mathrm{i}}$. Average $\mathrm{P}$ concentration of the leachate was determined by calculating the average of the two replications. Miscible displacement curve was produced by plotting mean P concentration against pore volume.

\subsection{Sequential fractionation Procedure}

To ascertain the forms of $\mathrm{P}$ that was lost during column leaching, the soil sample was fractionated before and after column leaching. The sequential extraction method of Hedley et al. (1982) as adopted by Kashem et al. (2004) was used. A $0.5 \mathrm{~g}$ portion of soil was weighed in 3 replications into a $50 \mathrm{ml}$ centrifuge tube. $30 \mathrm{ml}$ of deionized water was added, and the mixture was shaken for $16 \mathrm{hr}$ at approximately 80 excursions $\mathrm{min}^{-1}$. The mixture was centrifuged at $7000 \mathrm{x}$ g for $10 \mathrm{~min}$ and the extracts were filtered using a $0.45 \mu \mathrm{m}$ cellulose filter membrane.

The soil on the filter was rewashed into the $50 \mathrm{ml}$ centrifuge tube and the extraction procedure was repeated using $0.5 \mathrm{M} \mathrm{NaHCO}_{3}(\mathrm{pH}=8.2), 0.1 \mathrm{M} \mathrm{NaOH}$, and $1 \mathrm{M} \mathrm{HCl}$ in sequence on the same $0.5 \mathrm{~g}$ of soil. The residue after the sequential extraction process was analyzed for $\mathrm{P}$ by digesting in sulphuric acid-hydrogen peroxide mixture using the wet oxidation method of Akinremi et al. (2003).

The inorganic $\mathrm{P}$ in the extract was measured colorimetrically using the ascorbic acid-molybdate blue method of Murphy and Riley (1962). The extract total P concentration was determined using ICP-AES. The labile P concentration was defined as the sum of water and $0.5 \mathrm{M} \mathrm{NaHCO}_{3}$ extracts and the non-labile $\mathrm{P}$ was defined as 
the sum of extracted $\mathrm{P}$ in $0.1 \mathrm{M} \mathrm{NaOH}, 1 \mathrm{M} \mathrm{HCl}$ and the residual $\mathrm{P}$ as the $\mathrm{P}$ digested in the sulphuric acid-hydrogen peroxide (Kashem et al., 2004).

\subsection{Statistical Analysis}

A quadratic fit of the $\mathrm{P}$ advection data with pore volume was produced by regressing the concentration data with the pore volume using regression fit software in SigmaPlot 2000 (SPSS Inc. Sigma Plot for Windows), to model the $\mathrm{P}$ movement in an electrolyte saturated system. The first derivative of the quadratic equation represents an estimate of the rate of $\mathrm{P}$ movement as a function of change in pore-volume $(\mathrm{X})$. This serves as the basis for comparing $\mathrm{P}$ movement or advection rate at $2 \mathrm{PV}$ which corresponded to the pore volume at which maximum $\mathrm{P}$ was observed. Analysis of variance of SAS Institute (1990) was used to evaluate the significance of treatment effects and least significant difference (LSD) was used for means comparison.

\section{Results and Discussion}

\subsection{Effect of manure and manure application rate on P movement through the soil}

The concentration of phosphorus in the leachate increased and reached a maximum at about 2 PV (Figure 2a-c). The initial total $\mathrm{P}$ concentration in the leachate was about $22 \mathrm{mg} \mathrm{L}^{-1}$ in the surface soil and this rose steadily to a peak of about $28.8 \mathrm{mg} \mathrm{L}^{-1}$ at $2 \mathrm{PV}$ in the column packed with soil that received an annual manure application of $120 \mathrm{Mg} \mathrm{ha}^{-1}$. These concentrations are several orders of magnitude greater than that required to trigger eutropication in surface water (Sharpley et al., 1999). Sharpley et al. (1999) reported that a P concentration above $0.02 \mathrm{mg} \mathrm{L}^{-1}$ in lake water generally accelerates eutrophication.

Regardless of the rate of manure application, phosphorus leaching curve followed a similar pattern with all treatments reaching a peak at $2 \mathrm{PV}$ after which P concentration in the leachate declined. After the peak, P leaching curve assumed an exponential shape which leveled off at a concentration of about $6 \mathrm{mg} \mathrm{L}^{-1}$. Similar trend of $\mathrm{P}$ movement has been observed in other experiments related to the movement of $\mathrm{P}$ in soils receiving manure (Koopmans et al., 2004; Wright et al., 2006). Koopmans et al. (2004) attributed the trend to decrease in the concentration gradient between the soil surface and soil solution, the driving force of the P efflux. The results of this experiment demonstrated that the potential for significant loss of $\mathrm{P}$ from this surface soil exist if there are conducive hydrological conditions for the movement of large amount of water through the soil. Between 37 and $63 \%$ of the total P lost in the leachate was lost within the first $5 \mathrm{PV}$ in all treatments.

Inorganic $\mathrm{P}$ formed the bulk of total $\mathrm{P}$ determined in the leachate samples and followed the same leaching pattern as the total $\mathrm{P}$ with a peak reaching about $20 \mathrm{mg} \mathrm{L}^{-1}$ at $2 \mathrm{PV}$ after which the inorganic $\mathrm{P}$ concentration exponentially leveled off at about 5 to $6 \mathrm{mg} \mathrm{L}^{-1}$. The concentration of organic $\mathrm{P}$ in the leachate was generally small (Table 2). At the highest concentration of effluent total P (at 2 PV), organic P accounted for less than one-third of the effluent P. Although the soils had a long history of cattle manure application and cattle manure addition has been reported to result in leachate with a high percentage of organic P (Idowu et al., 2008), this was not the case in the present study. Idowu et al. (2008) reported that as much as $63 \%$ of P eluted from cattle manure amended soil column was in the form of organic P. This was contrary to the results of this study and the discrepancy may be due to the fact that in the study by Idowu et al. (2008), leachate was collected from soils that were amended with fresh cattle manure while in this study leachate was collected from soils with history of cattle manure application. It is possible that organic $\mathrm{P}$ in manure undergo chemical transformations upon addition to soils in the field. He et al. (2008) reported that 20 years of repeated poultry litter application did not result in the accumulation of organic $\mathrm{P}$ in soil and concluded that organic $\mathrm{P}$ must have been converted to other forms of $\mathrm{P}$. Sharpley et al. (1984) reported a rapid decrease in soil organic P following years of cattle manure application due to mineralization of organic P. Parham et al. (2002) reported that long-term application of cattle manure promoted microbiological activities and enhanced $\mathrm{P}$ cycling.

The effect of manure application on effluent $P$ gradually decreased from the surface soil $(0-15 \mathrm{~cm})$ to the subsoil (30-60 cm). For example, the total P eluted from the column packed with soil from $60 \mathrm{Mg}$ ha $^{-1}$, non-irrigated plot decreased from $28.2 \mathrm{mg}$ in the surface to $9.7 \mathrm{mg}$ in the subsurface $15-30 \mathrm{~cm}$ and finally to $0.09 \mathrm{mg}$ in the subsurface $30-60 \mathrm{~cm}$ (Table 3). The concentration of effluent $P$ from the subsurface $30-60 \mathrm{~cm}$ in the manured 60 $\mathrm{Mg} \mathrm{ha}^{-1}$ plot was not significantly different from that of the control at the same depth. Analysis of variance showed significant effect of soil depth on the amount of leachate $\mathrm{P}(p<0.05)$. Mean comparison showed that the amount of leachate $P$ from surface $0-15 \mathrm{~cm}$ soil was significantly greater than that of the sub-surface $15-30 \mathrm{~cm}$ soil, which was in turn significantly greater than the leachate $P$ from the sub-surface $30-60 \mathrm{~cm}$ soil. A similar decrease in the soil total $\mathrm{P}$ concentration with soil depth was observed in all plots sampled for this study (Table 3). The soil total P decreased from $462 \mathrm{mg}$ in the surface soil of a non-irrigated soil that annually received $60 \mathrm{Mg}$ $\mathrm{ha}^{-1}$ of manure to $108 \mathrm{mg}$ in the subsoil $30-60 \mathrm{~cm}$. This value was not significantly different from the amount of 
total P ( $89 \mathrm{mg}$ ) in the subsoil $30-60 \mathrm{~cm}$ of the control soil (Table 3).

The leachate $\mathrm{P}$ concentration increased with increasing manure application rate (Fig. 2). Analysis of variance showed significant effect of manure application rate on leachate total $\mathrm{P}(p<0.1)$. The greatest amount of $\mathrm{P}(34$ $\mathrm{mg}$ ) was leached from surface soil of plot that received the highest rate of cattle manure while the lowest $(2.7 \mathrm{mg})$ was leached from the control surface soil. The amount of P leached from $120 \mathrm{Mg} \mathrm{ha}^{-1}$ plot was significantly greater than those from the two plots that received $60 \mathrm{Mg} \mathrm{ha}^{-1}(\mathrm{p}<0.05)$. The result showed that the rate of manure application has a direct influence on the risk of P loss from soil. Griffin et al. (2003) reported a linear increase in soil P with increasing rate of P application. Sharpley and Tunney (2000) indicated that the build up of soil $\mathrm{P}$ resulting from continuous application of manure could increase the potential of $\mathrm{P}$ loss.

On the whole, about $5-7 \%$ of the soil total $\mathrm{P}$ was lost in $20 \mathrm{PV}$ of leachate $\mathrm{P}$ in manure amended surface soil, while $2 \%$ was lost in the control surface soil (Table 3). The greater percent of total P lost in leachate from manure amended soil than the control soil might be due to increasing solubility of soil $\mathrm{P}$ with manure application. This is probably a reflection of greater degree of $\mathrm{P}$ saturation in manured soil.

\subsection{Effect irrigation on P movement through the soil column}

Evaluation of the effect of irrigation on P mobility in the soil over the $20 \mathrm{PV}$ showed that leachate P from the surface, $60 \mathrm{Mg} \mathrm{ha}^{-1}$ non-irrigated plot was significantly greater than that from the $60 \mathrm{Mg} \mathrm{ha}^{-1}$ irrigated plot ( $p$ $<0.05$ ). However, the reverse was the case for the subsurface soils. The total leachate $\mathrm{P}$ from the irrigated sub-surface $(15-30 \mathrm{~cm})$ plot was significantly greater than that of the non-irrigated plot. The total P leached from the surface and sub-surface $15-30$ and 30-60 cm soil from the irrigated plot at $60 \mathrm{Mg}^{-1}$ were $26.7,12.9$, and $0.5 \mathrm{mg}$, respectively, those from the non-irrigated soil were $28.2,9.7$, and $0.1 \mathrm{mg}$, respectively. The smaller leachate $\mathrm{P}$ in the surface soil and the concomitant greater leachate $\mathrm{P}$ in subsurface soil of the irrigated plot compared with the non-irrigated plot might be due to greater movement of $\mathrm{P}$ down the profile under irrigation. This finding corroborated the report of Warren and Chang (2001) who found that the risk of ground water contamination with $\mathrm{P}$ from manure was greater in irrigated than nonirrigated plots after 16 years of cattle manure application. Shuman (2001) also reported that P leaching was influenced by irrigation in golf green. It was possible that irrigation management provided a hydrological condition that positively influenced in situ $\mathrm{P}$ movement down the soil profile.

\subsection{The rate of $P$ movement through the soil column}

The advective rate of $\mathrm{P}$ through the soil column was directly related to the rate of manure application (Table 4). This might be due to lower bond energy of $\mathrm{P}$ as manure application rate increased. The higher the rate of manure application the higher the $\mathrm{P}$ load to soil, and the more saturated the $\mathrm{P}$ retention sites of soil becomes. As the sorption site becomes increasingly saturated, subsequent $\mathrm{P}$ retained are held less tightly to the soil and, thus, can be lost more readily (Kasheem et al., 2004). While the magnitude of $\mathrm{P}$ advection slope was $6.5 \mu \mathrm{g} \mathrm{L}^{-1} \mathrm{PV}^{-1}$ in the surface soil that received $120 \mathrm{Mg} \mathrm{ha}^{-1}$, it was $3.2 \mu \mathrm{g} \mathrm{L}{ }^{-1} \mathrm{PV}^{-1}$ in surface soil that received $60 \mathrm{Mg} \mathrm{ha}^{-1}$ and $0.2 \mu \mathrm{g}$ $\mathrm{L}^{-1}$ in the control surface soil (Table 4). This also demonstrated the ease of $\mathrm{P}$ loss from soil with high rate of manure application.

Although the rate of $\mathrm{P}$ movement was the same in the surface of irrigated and non-irrigated soils that both received $60 \mathrm{Mg} \mathrm{ha}^{-1}$, there was about 4-fold increase in the rate of $\mathrm{P}$ movement in the subsurface irrigated soil compared with the non-irrigated counterpart. At $2 \mathrm{PV}$, the rate of $\mathrm{P}$ advection was $6 \mu \mathrm{g} \mathrm{L}^{-1} \mathrm{PV}^{-1}$ for the surface soil of both irrigated and non-irrigated plots while it was 2.5 and $0.6 \mu \mathrm{g} \mathrm{L}^{-1} \mathrm{PV}^{-1}$ for the subsurface irrigated and non-irrigated soils, respectively. Thus, irrigation did not only significantly influence the amount of P leached from the irrigated soil compared with the non-irrigated soil, it also substantially increased the rate of in situ downward movement of $\mathrm{P}$ in this soil layer.

\subsection{P forms lost through column leaching}

Following column leaching study, there was a significant $(p<0.05)$ decrease of between 27 to $40 \%$ in the amount of water extractable $\mathrm{P}$ in the manured soil indicating that an appreciable quantity of this $\mathrm{P}$ fraction was lost during column leaching (Fig. 3). However, there was an increase in $\mathrm{NaHCO}_{3}-\mathrm{P}$ after column leaching. The increase was significant in the control surface soil as well as in all the treatments (except $120 \mathrm{Mg} \mathrm{ha}^{-1}$ treatment) for the subsoil $15-30 \mathrm{~cm}$ (Fig. 3). The $\mathrm{NaHCO}_{3}-\mathrm{P}$ significantly $(\mathrm{p}<0.05)$ increased from $435 \mathrm{mg} \mathrm{kg}^{-1}$ before column leaching to $484 \mathrm{mg} \mathrm{kg}^{-1}$ after column leaching in the non-irrigated soil that received $60 \mathrm{Mg} \mathrm{ha}^{-1}$ annual manure application. The increase in $\mathrm{NaHCO}_{3}-\mathrm{P}$ after column leaching was not expected because $\mathrm{NaHCO}_{3}-\mathrm{P}$, along with water-P, is often classified as labile $\mathrm{P}$ and therefore is the form of $\mathrm{P}$ that could easily be lost through leaching. Sodium bicarbonate P has been operationally defined as representing surface adsorbed P (Goh, 2008). 
It is possible that the dissolution of solid phase $\mathrm{P}$ resulted in the adsorption of $\mathrm{P}$ which subsequently increased $\mathrm{NaHCO}_{3}-\mathrm{P}$ fraction. The increase could also indicate the redistribution of various $\mathrm{P}$ forms during column leaching and the subsequent drying process.

There were decreases in $\mathrm{NaOH}-, \mathrm{HCl}$ - and residual- $\mathrm{P}$ following column leaching; the decrease was significant for some treatments in the surface and sub-surface soils (Fig. 4). There was a decrease of between 0.1 and $22 \%$ in NaOH-P and between 3 and $14 \%$ in HCl-P after column leaching in the surface soil (Fig. 4). Similar percent decrease was also observed in the subsoil $15-30 \mathrm{~cm}$ (Fig. 4). The decrease in these forms of P following column leaching could imply that they were lost from the soil during column leaching. This could be of environmental concern because these P forms are often regarded as non-labile and therefore posed little or no environmental threat (Dustin and Wang, 2006). The decrease could also indicate the transformation of non-labile $\mathrm{P}$ forms to more labile $\mathrm{P}$ during the process of leaching and drying. Such transformation could explain the increase observed in $\mathrm{NaHCO}_{3}-\mathrm{P}$ after column leaching. Faridullah et al. (2008) hinted that HCl-P could be mobilized to labile $\mathrm{P}$ fraction if the later was getting depleted. Rewetting and drying of soil has been shown to increase soil $\mathrm{P}$ solubility which could imply the transformation of insoluble soil P to more soluble forms (Olila et al., 1997; Venterink et al., 2002). Venterink et al. (2002) reported that re-wetting of soil increased the soil P solubility under field condition. Olila et al. (1997) reported increased P release following drying and re-wetting processes. In a laboratory study, Guo and Yost (1998) showed that available P in soil is often buffered by the less available $\mathrm{P}$ forms. The transformation of non-labile $\mathrm{P}$ to more labile $\mathrm{P}$ form is instructive; indicating that the so-called recalcitrant $\mathrm{P}$ may not be as recalcitrant as often assumed, and may as well be environmentally significant.

\subsection{Correlation between $P$ forms and leachate total $P$}

The contribution of the different $\mathrm{P}$ forms to total $\mathrm{P}$ lost from the soil was further evaluated by correlation analysis (Table 5). A positive significant correlation $(\mathrm{p}<0.05)$ between water extractable $\mathrm{P}$ and leachate $\mathrm{P}$ showed the significant contribution of water-P to P loss through leaching. This supports the commonly held view that water-P is vulnerable to loss by runoff and leaching (Sharpley and Moyer, 2000). The significant positive correlation was observed between $\mathrm{NaHCO}_{3}-\mathrm{P}$ and leachate $\mathrm{P}$ despite the fact that $\mathrm{NaHCO}_{3}-\mathrm{P}$ increased following column leaching. This could imply that $\mathrm{NaHCO}_{3}-\mathrm{P}$ was actually lost but the loss was compensated for by the transformation of the non-labile $\mathrm{P}$ forms to $\mathrm{NaHCO}_{3}-\mathrm{P}$ during the leaching or the drying process. A significant positive correlation between HCl-P and leachate $\mathrm{P}$ could be due to the direct contribution of HCl-P to leachate $\mathrm{P}$ or the indirect contribution of $\mathrm{HCl}-\mathrm{P}$ to leachate $\mathrm{P}$ through its transformation to $\mathrm{NaHCO}_{3}-\mathrm{P}$ or a combination of both direct and indirect contributions. The possibility of $\mathrm{P}$ transformation from less labile to more labile form could also ensure the replenishment of soil available P under cropping condition. Guo and Yost (1998) reported that decrease in HCl-P and residual-P was significantly correlation with plant uptake probably due to compensatory transformation to more labile P form. Other authors such as Hedley et al. 1982 and McKenzie et al. 1992 had also reported changes in HCl-P and residual P due to plant P removal. Thus, all forms of manure $\mathrm{P}$ are potentially available to plant under suitable conditions.

\section{Conclusion}

In this study, inorganic $\mathrm{P}$ was the major $\mathrm{P}$ form lost during column leaching from soil with long history of manure application. The amount of $\mathrm{P}$ lost from the soil was directly related to the rate of manure application which showed that increasing manure application rate has a direct effect on the potential of $\mathrm{P}$ loss to the environment. Irrigation activity enhanced the in situ movement of $\mathrm{P}$ down the soil profile which was reflected in greater leachate $\mathrm{P}$ in the subsoil of irrigated soil compared with that of the non-irrigated soil. The $\mathrm{P}$ lost during soil column leaching was mostly from the water extractable P form. Some less soluble P forms ( $\mathrm{NaOH}-, \mathrm{HCl}-$ and residual P) were either lost or transformed to more labile $\mathrm{NaHCO}_{3}-\mathrm{P}$.

\section{References}

Akinremi, O. O., Armisen, N., Kashem, A., \& Janzen, H. H. (2003). Evaluation of analytical methods for total P in organic amendments. Communications in Soil Science and Plant Analysis, 34, 2987-2997.

Akinremi, O. O., \& Cho, C. M. (1991). Phosphate and accompanying cations in a calcareous cation-exchange resin system. Soil Science Society of America Journal, 55, 959-964.

Anderson, B. H. \& Magdoff, F. R. (2005). Relative movement and soil fixation of soluble organic and inorganic phosphorus. Journal of Environmental Quality, 34, 2228-2233.

Borggaard, O. K., Jorgensen, J. P., Morberg, J. P., \& Raben-Lange, B. (1990). Influence of organic matter on phosphate adsorption by aluminum and iron oxides in sandy soils. Journal of Soil Science, 41, 443-449.

Borling, K., Otabbong, E., \& Barberis, E. (2001). Phosphorus sorption in relation to soil properties in some 
cultivated Swedish soils. Nutrient Cycling in Agroecosystems, 59, 39-46.

Castro, B., \& Torrent, J. (1998). Phosphate sorption by calcareous vertisols and inceptisols as evaluated from extended P sorption curves. European Journal of Soil Science, 49, 661-667.

Chang, C., Whalen, J., \& Hao, X. (2005). Increase in phosphorus concentration of a clay loam surface soil receiving repeated annual feedlot cattle manure applications in southern Alberta. Canadian Journal of Soil Science, 85, 589-597.

Chardon, W. J., \& Van Faassen, H. F. (1999). Soil indicators for critical source areas of phosphorus leaching. Rapporten Programma Geintegreerd Bodemonderzoek, 22. Netherlands Integrated Soil Research Program, Wageningen, the Netherlands.

Cho, C. M., Strong, J., \& Racz, G. J. (1970). Convective transport of orthophosphate (P-31 and -32) in several Manitoba soils. Canadian Journal of Soil Science, 50, 303-315.

Daly, K., Jeffrey, D., \& Tunney, H. (2001). The effect of soil type on phosphorus sorption capacity and desorption dynamics in Irish grassland soils. Soil Use and Management, 17, 12-20.

Djodjic, F., Bergström, L., Ulén, B., \& Shirmohammadi, A. (1999). Mode of transport of surface-applied phosphorus-33 through a clay and sandy soil. Journal of Environmental Quality, 28, 1273-1282.

Dustin, L. H., \& Wang, J. J. (2006). Fractionation and sorption of inorganic phosphorus in Louisiana calcareous soils. Soil Science, 171, 39-51.

Faridullah, Yamamoto, S., Irshad, M., Uchiyama, T., \& Honna, T. (2008). Phosphorus fractionation in chicken and duck litter burned at different temperatures. Soil Science, 173, 287-295.

Goh, K. M. (2008). Plant Availability of soil phosphorus forms accumulated from long-term superphosphate applications to irrigated pastures Communications in Soil Science and Plant Analysis, 39, 1979-1992

Graetz, D. A., \& Nair, V. D. (1995). Fate of phosphorus in Florida spodosols contaminated with cattle manure. Ecological Engineering, 5, 163-181.

Griffin, T. S., Honeycutt, C. W., \& He, Z. (2003). Changes in soil phosphorus from manure application. Soil Science Society of America Journal, 67, 645-653.

Guo, F., \& Yost, R. S. (1998). Partitioning soil phosphorus into three discrete pools of differing availability. Soil Science, 163, 822-833

Hao, X., Chang, C. \& Li, X. (2004). Long-term and residual effects of cattle manure application on distribution of $\mathrm{P}$ in soil aggregates. Soil Science, 169, 715-728.

He, Z., Honeycutt, C. W., Cade-Menun, B. J., Senwo, Z. N., \& Tazisong, I. A. (2008). Phosphorus in poultry litter and soil: Enzymatic and nuclear magnetic resonance characterization. Soil Science Society of America Journal, 72, 1424-1433.

Heckrath, G., Brookes, P. C., Poulton, P. R., \& Goulding, K. W. T. (1995). Phosphorus leaching from soils containing different phosphorus concentrations in the Broadbalk experiment. Journal of Environmental Quality, 24, 904-910.

Hedley, M. J., Stewart, J. W. B., \& Chauhan, B. S. (1982). Changes in inorganic soil phosphorus fractions induced by cultivation practices and by laboratory incubations. Soil Science Society of America Journal, 46, 970-976.

Idowu, M. K., Ige, D. V., \& Akinremi, O. O. (2008). Elution of inorganic and organic phosphorus from surface applied organic amendments. Canadian Journal of Soil Science, 88, 709-717.

Iyamuremye, F., Dick, R. P. \& Baham, J. (1996). Organic amendments and phosphorus dynamics. I. Phosphorus chemistry and sorption. Soil Science, 161, 426-435.

Kashem, M. A., Akinremi, O. O., \& Racz, G. J. (2004). Phosphorus fractions in soil amended with organic and inorganic phosphorus sources. Canadian Journal of Soil Science, 84, 83-90.

Koopmans, G., Chardon, W., de Willigen, P., \& van Riemsdijk, W. (2004). Phosphorus desorption dynamics in soil and the link to a dynamic concept of bioavailability. Journal of Environmental Quality, 33, 1393-1402.

McKenzie, R. H., Stewart, J. W. B., Dormaar, J. F., \& Schaalje, G. B. (1992). Long-term crop rotation and fertilizer effects on phosphorus transformations. II. In a Luvisolic soil. Canadian Journal of Soil Science, 72, 581-589. 
Murphy, J. P., \& Riley, J. P. (1962). A modified single solution method for the determination of phosphate in natural waters. Analytica Chimica Acta, 27, 31-36.

Olatuyi, S. O., Akinremi, O. O., Flaten, D. N., \& Crow, G. H. (2009). Accompanying cations and anions affect the diffusive transport of phosphate in a model calcareous soil system. Canadian Journal of Soil Science, 89, 179-188.

Olila, O. G., Reddy, K. R., \& Stites, D. L. (1997). Influence of draining on soil phosphorus forms and distribution in a constructed wetland. Ecological Engineering, 9, 157-169.

Oliviera, I. B., Demond, A. H., \& Salehzadeh, A. (1996). Packing of sands for the production of homogeneous porous media. Soil Science Society of America Journal, 60, 49-53.

Parham, J., Deng, S., Raun, W., \& Johnson, G. (2002). Long-term cattle manure application in soil: I. Effect on soil phosphorus levels, microbial biomass $\mathrm{C}$, and dehydrogenase and phosphatase activities. Biology and Fertility of Soils, 35, 328-337.

SAS Institute. (1990). SAS procedure guide, version 6, $3^{\text {rd }}$ Ed., SAS Institute: Cary, NC.

Sharpley, A. N., Daniel, T., Sims, T., Lemunyon, J., Stevens, R., \& Parry, R. (1999). Agriculture phosphorus and eutrophication. ARS-149, U.S. Dep. of Agric., Washington, D.C. 42 pp.

Sharpley, A., \& Moyer, B. (2000). Phosphorus forms in manure and compost and their release during simulation rainfall. Journal of Environmental Quality, 29, 1462-1469.

Sharpley, A. N., Smith, S. J., Stewart, B. A., \& Mathers, A. C. (1984). Forms of phosphorus in soil receiving cattle feedlot waste. Journal of Environmental Quality, 13, 211-215.

Sharpley, A., \& Tunney, H. (2000). Phosphorus research strategies to meet agricultural and environmental challenges in the 21st century. Journal of Environmental Quality, 29, 176-181.

Shuman, L. M. (2001). Phosphate and nitrate movement through simulated Golf greens. Water, Air, and Soil Pollution, 129, 305-318.

Sims, J. T., Simard, R. R., \& Joern, B. C. (1998). Phosphorus loss in agricultural drainage: Historical perspective and current research. Journal of Environmental Quality, 27, 277-293.

Sommerfeldt, T. G., \& Chang, C. (1985). Changes in soil properties under annual application of feedlot manure and different tillage practices. Soil Science Society of America Journal, 49, 983-987.

Sui, Y., \& Thompson, M. L. (2000). Phosphorus sorption, desorption, and buffering capacity in a biosolids-amended mollisol. Soil Science Society of America Journal, 64, 164-169.

Turner, B. L., \& Haygarth, P. M. (2000). Phosphorus forms and concentrations in leachate under four grassland soil types. Soil Science Society of America Journal, 64, 1090-1099.

Venterink, H. O., Davidsson, T. E., Kiehl, K., \& Leonardson. L. (2002). Impact of drying and re-wetting on N, P and K dynamics in a wetland soil. Plant and Soil, 243, 119-130.

Whalen, J. K., and Chang, C. (2001). Phosphorus accumulation in cultivated soils from long-term annual application of cattle feed-lot manure. Journal of Environmental Quality, 30, 229-237.

Whalen, J. K., Chang, C., \& Clayton, G. W. (2000). Cattle manure amendments can increase the pH of acid soils. Soil Science Society of America Journal, 64, 962-966.

Wright, C. R., Amrani, M., Akbar, M. A., Heaney, D. J., \& Vanderwel, D. S. (2006). Determining phosphorus release rates to runoff from selected Alberta soils using laboratory rainfall simulation. Journal of Environmental Quality, 35, 806-814.

Zhou, M., \& Li, Y. (2001). Phosphorus-sorption characteristics of soils and limestone from the Southern Everglades and adjacent farmlands. Soil Science Society of America Journal, 65, 1404-1412. 
Table 1. Initial soil properties (as measured in 1973) and mean manure characteristics

\begin{tabular}{|l|c|c|c|}
\hline \multirow{2}{*}{ Soil Properties } & \multicolumn{3}{|c|}{ Depth $(\mathrm{cm})$} \\
\cline { 2 - 4 } & $0-15$ & $15-30$ & $30-60$ \\
\hline Sand $\left(\mathrm{g} \mathrm{kg}^{-1}\right)$ & 386 & 387 & 478 \\
\hline Silt $\left(\mathrm{g} \mathrm{kg}^{-1}\right)$ & 220 & 213 & 225 \\
\hline Clay $\left(\mathrm{g} \mathrm{kg}^{-1}\right)$ & 394 & 400 & 297 \\
\hline $\mathrm{pH}$ & 7.7 & 7.8 & 7.9 \\
\hline Organic C $\left(\mathrm{g} \mathrm{kg}^{-1}\right)$ & 14.6 & 11.0 & 5.7 \\
\hline Olsen $\mathrm{P}\left(\mathrm{mg} \mathrm{kg}^{-1}\right)$ & 10.1 & 3.9 & 1.3 \\
\hline Total P $\left(\mathrm{g} \mathrm{kg}^{-1}\right)$ & 0.69 & 0.69 & 0.58 \\
\hline Total N $\left(\mathrm{g} \mathrm{kg}^{-1}\right)$ & 25.7 & 22.0 & 13.0 \\
\hline Manure properties $($ average of first 30 years $)$ \\
\hline Total C $\left(\mathrm{g} \mathrm{kg}^{-1}\right)$ & $195.6+12.1$ \\
\hline Total N $\left(\mathrm{g} \mathrm{kg}^{-1}\right)$ & $16.5+0.8$ \\
\hline Total P $\left(\mathrm{g} \mathrm{kg}^{-1}\right)$ & $6.44+0.26$ \\
\hline Water content $\left(\mathrm{g} \mathrm{kg}^{-1}\right)$ & $665+10$ \\
\hline
\end{tabular}

Table 2. Effect of irrigation and rate of manure application on organic $\mathrm{P}$ concentration $\left(\mathrm{mg} \mathrm{L}^{-1}\right)$ in leachate from surface and subsurface soil

\begin{tabular}{|l|l|c|c|}
\hline \multirow{3}{*}{ Soil Depth } & \multirow{2}{*}{ Treatment } & \multicolumn{2}{|c|}{ Pore Volume } \\
\cline { 3 - 4 } & & $0-2$ & $2-20$ \\
\hline \multirow{5}{*}{$0-15 \mathrm{~cm}$} & CI & 0.29 & 0.00 \\
\cline { 2 - 4 } & $60 \mathrm{MNI}$ & 0.39 & 0.02 \\
\cline { 2 - 4 } & $60 \mathrm{MI}$ & 0.41 & 0.38 \\
\cline { 2 - 4 } & $120 \mathrm{MI}$ & 7.10 & 0.42 \\
\hline \multirow{5}{*}{$15-30 \mathrm{~cm}$} & $\mathrm{CI}$ & 0.08 & 0.00 \\
\cline { 2 - 4 } & $60 \mathrm{MNI}$ & 0.00 & 0.00 \\
\cline { 2 - 4 } & $60 \mathrm{MI}$ & 0.62 & 0.14 \\
\cline { 2 - 4 } & $120 \mathrm{MI}$ & 0.59 & 0.05 \\
\hline \multirow{3}{*}{$30-60 \mathrm{~cm}$} & CI & 0.00 & 0.00 \\
\cline { 2 - 4 } & $60 \mathrm{MNI}$ & 0.09 & 0.00 \\
\cline { 2 - 4 } & $60 \mathrm{MI}$ & 0.11 & 0.05 \\
\cline { 2 - 4 } & $120 \mathrm{MI}$ & 0.02 & 0.00 \\
\hline
\end{tabular}

Treatments include CI as Irrigated Control, 60MNI as $60 \mathrm{Mgha}^{-1} \mathrm{yr}^{-1}$ Non-irrigated, 60MI as $60 \mathrm{Mgha}^{-1} \mathrm{yr}^{-1}$ Irrigated, and $120 \mathrm{MI}$ as $120 \mathrm{Mgha}^{-1} \mathrm{yr}^{-1}$ Irrigated. 
Table 3. Total P removed from the soil column by 20 pore volumes of $0.01 \mathrm{M} \mathrm{CaCl}_{2}$

\begin{tabular}{|c|c|c|c|c|c|c|c|c|c|}
\hline \multirow{3}{*}{ Treatment } & \multicolumn{3}{|c|}{ Leachate $\mathrm{P}(\mathrm{mg})$} & \multicolumn{3}{|c|}{ Soil Total P(mg) } & \multicolumn{3}{|c|}{$\% \mathrm{P}$ in Leachate } \\
\hline & \multicolumn{9}{|c|}{ Soil Depth $(\mathrm{cm})$} \\
\hline & $0-15$ & $15-30$ & $30-60$ & $0-15$ & $15-30$ & $30-60$ & $0-15$ & $15-30$ & $30-60$ \\
\hline $\mathrm{CI}$ & $2.72 \mathrm{aD}$ & $0.04 \mathrm{~b} \mathrm{D}$ & $0.00 \mathrm{~b} \mathrm{~B}$ & 167.7 a C & $103.4 \mathrm{~b} \mathrm{C}$ & 89.2 c B & 1.62 & 0.04 & 0.00 \\
\hline $60 \mathrm{MNI}$ & $28.2 \mathrm{a} \mathrm{C}$ & $9.73 \mathrm{~b} \mathrm{C}$ & $0.09 \mathrm{c} \mathrm{B}$ & 462.8 a B & 247.8 b B & 108.6 c B & 6.09 & 3.92 & 0.08 \\
\hline 60MI & 26.8 a B & $12.9 \mathrm{~b} \mathrm{~B}$ & 0.48 с B & $533.6 \mathrm{a} \mathrm{A}$ & $232.7 \mathrm{~b} \mathrm{~B}$ & 80.4 c B & 5.01 & 5.55 & 0.60 \\
\hline $120 \mathrm{MI}$ & $34.1 \mathrm{a} \mathrm{A}$ & $24.9 \mathrm{~b} \mathrm{~A}$ & $1.81 \mathrm{c} \mathrm{A}$ & 506.6 a A & $450.4 \mathrm{~b} \mathrm{~A}$ & $176.3 \mathrm{c} \mathrm{A}$ & 6.72 & 5.51 & 1.03 \\
\hline
\end{tabular}

Figures in a row for leachate or soil total $\mathrm{P}$ followed by the same small case letter are not significantly different $(p>0.05)$.

Figures in the same columns followed by the same upper case letter are not significantly different $(p>0.05)$

Treatments include CI as Irrigated Control, 60MNI as $60 \mathrm{Mgha}^{-1} \mathrm{yr}^{-1}$ Non-irrigated, 60MI as $60 \mathrm{Mgha}^{-1} \mathrm{yr}^{-1}$ Irrigated, and $120 \mathrm{MI}$ as $120 \mathrm{Mgha}^{-1} \mathrm{yr}^{-1}$ Irrigated.

Table 4. Impact of manure application rate and irrigation on the rate of P movement through the soil column, estimated using $\mathrm{P}$ concentrations

\begin{tabular}{|c|c|c|c|c|c|c|c|}
\hline \multirow{4}{*}{ Treatment } & \multicolumn{3}{|c|}{ Model Coefficients } & \multirow[t]{2}{*}{$\mathrm{R}^{2}$} & \multirow[t]{2}{*}{$\begin{array}{c}\mathrm{SE} \\
\left( \pm \mathrm{ug} \mathrm{L}^{-1}\right)\end{array}$} & \multirow[t]{2}{*}{$\begin{array}{l}\text { Advection Rate } \\
\text { (ug L L } \mathrm{PV}^{-1} \text { ) }\end{array}$} & \multirow[t]{2}{*}{$\begin{array}{l}\text { Rate at } \\
2 \mathrm{PV}\end{array}$} \\
\hline & $\mathrm{a}$ & $\mathrm{b}$ & $\mathrm{c}$ & & & & \\
\hline & \multicolumn{7}{|c|}{ Total P Concentration vs Pore Volume } \\
\hline & \multicolumn{7}{|c|}{$0-15 \mathrm{~cm}$} \\
\hline $\mathrm{CI}$ & -0.086 & 0.003 & 1.249 & 0.735 & $0.089^{x}$ & $-0.172 \mathrm{X}+0.003^{\mathrm{w}}$ & $-0.34^{v}$ \\
\hline $60 \mathrm{MNI}$ & -1.592 & 0.042 & 19.042 & 0.922 & 1.324 & $-3.185 X+0.042$ & -6.33 \\
\hline $60 \mathrm{MI}$ & -1.590 & 0.045 & 18.248 & 0.914 & 1.311 & $-3.179 X+0.045$ & -6.31 \\
\hline \multirow[t]{2}{*}{$120 \mathrm{MI}$} & -3.241 & 0.107 & 28.779 & 0.918 & 2.128 & $-6.481 X+0.107$ & -13.1 \\
\hline & \multicolumn{7}{|c|}{$15-30 \mathrm{~cm}$} \\
\hline $\mathrm{CI}$ & -0.004 & 0.0001 & 0.081 & 0.423 & 0.014 & $-0.008 \mathrm{X}+0.0001$ & -0.02 \\
\hline $60 \mathrm{MNI}$ & -0.145 & -0.002 & 4.651 & 0.780 & 0.562 & $-0.290 X-0.002$ & -0.58 \\
\hline $60 \mathrm{MI}$ & -0.635 & 0.0174 & 8.040 & 0.926 & 0.496 & $-1.271 \mathrm{X}+0.0174$ & -0.52 \\
\hline \multirow[t]{2}{*}{$120 \mathrm{MI}$} & -1.725 & 0.047 & 18.760 & 0.867 & 1.891 & $-3.450 X+0.017$ & -6.88 \\
\hline & \multicolumn{7}{|c|}{$30-60 \mathrm{~cm}$} \\
\hline $\mathrm{CI}$ & NA & NA & NA & NA & NA & & \\
\hline $60 \mathrm{MNI}$ & -0.013 & 0.001 & 0.086 & 0.243 & 0.037 & $-0.025 X+0.001$ & -0.05 \\
\hline $60 \mathrm{MI}$ & -0.054 & 0.0014 & 0.5101 & 0.336 & 0.226 & $-0.108 \mathrm{X}+.0014$ & -0.21 \\
\hline $120 \mathrm{MI}$ & -0.126 & 0.0035 & 1.3606 & 0.558 & 0.306 & $-0.252 X+0.001$ & -0.50 \\
\hline
\end{tabular}

Treatments include CI as Irrigated Control, 60MNI as $60 \mathrm{Mgha}^{-1} \mathrm{yr}^{-1} \mathrm{Non}$-Irrigated, $60 \mathrm{MI}$ as 60 $\mathrm{Mgha}^{-1} \mathrm{yr}^{-1}$ Irrigated, and $120 \mathrm{MI}$ as $120 \mathrm{Mgha}^{-1} \mathrm{yr}^{-1}$ Irrigated;

Quadratic model implies $\mathrm{Y}=\mathrm{aX} \mathrm{X}^{2}+\mathrm{bX}+\mathrm{C}$, where $\mathrm{X}$ is pore volume of $0.01 \mathrm{M} \mathrm{CaCl}_{2}$ electrolyte, $\mathrm{Y}$ is ICP-P concentration $\left(\mathrm{mg} \mathrm{L}^{-1}\right)$, and $\mathrm{a}, \mathrm{b}, \mathrm{c}$ are constants;

SE implies standard error of model estimates;

Rate of $\mathrm{P}$ movement is the first derivative of the quadratic model;

Negative value of rate was due to decreasing $\mathrm{P}$ concentration at $2 \mathrm{PV}$ and above;

NA means not available due to very low concentration of TP concentration. 
Table 5. Correlation between forms of $\mathrm{P}$ in the soil and the maximum and minimum concentrations of $\mathrm{P}$ in the leachate $(n=8)$

* Significant correlation at $p=0.05$.

\begin{tabular}{|l|c|c|}
\hline \multirow{2}{*}{$\begin{array}{c}\text { Soil Extracts } \\
\left(\mathrm{mgkg}^{-1}\right)\end{array}$} & \multicolumn{2}{|c|}{ Leachate $\mathrm{P}\left(\mathrm{mgL}^{-1}\right)$} \\
\cline { 2 - 3 } & \multicolumn{2}{|c|}{$0-15 \mathrm{~cm}$} \\
\hline Water-P & $0.97^{*}$ & $0.78^{*}$ \\
\hline NaHCO $_{3}$-P & $0.95^{*}$ & $0.83^{*}$ \\
\hline NaOH-P $^{*}$ & 0.55 & 0.51 \\
\hline HCl-P & $0.99^{*}$ & $0.82^{*}$ \\
\hline Residual & 0.12 & 0.00 \\
\hline Labile-P & $0.97^{*}$ & $0.82^{*}$ \\
\hline Non-Labile P & $0.94^{*}$ & $0.76^{*}$ \\
\hline & $15-30 \mathrm{~cm}^{*}$ \\
\hline Water-P & $0.92^{*}$ & 0.05 \\
\hline NaHCO ${ }_{3}-\mathrm{P}$ & $0.87^{*}$ & 0.02 \\
\hline NaOH-P & 0.31 & 0.14 \\
\hline HCl-P & 0.67 & 0.47 \\
\hline Residual & 0.32 & 0.14 \\
\hline Labile-P & $0.89^{*}$ & 0.03 \\
\hline Non-Labile P & 0.66 & 0.45 \\
\hline
\end{tabular}

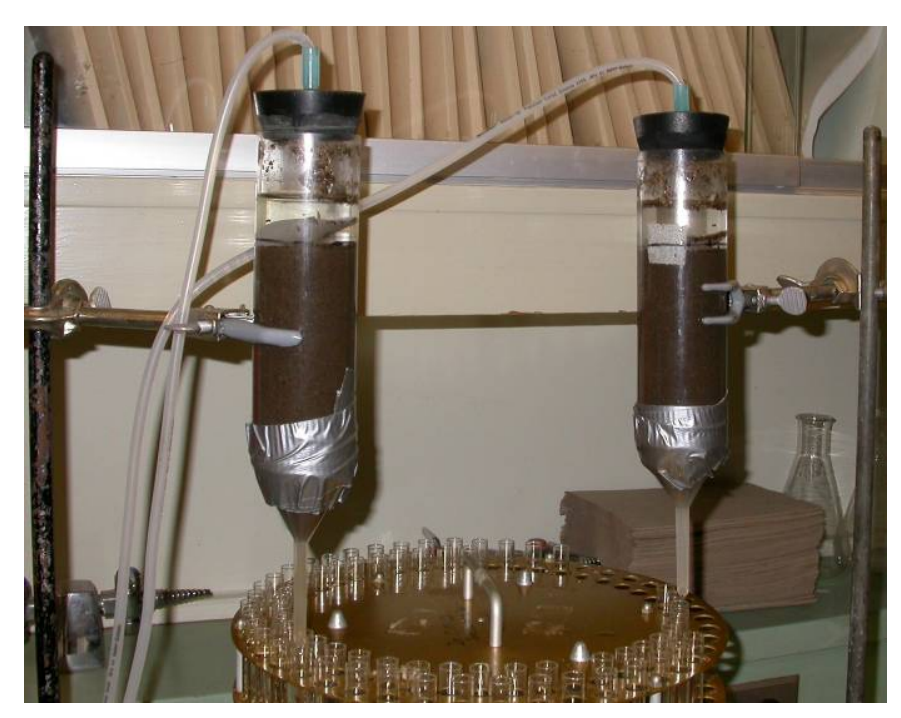

Figure 1. Soil column leaching set up 

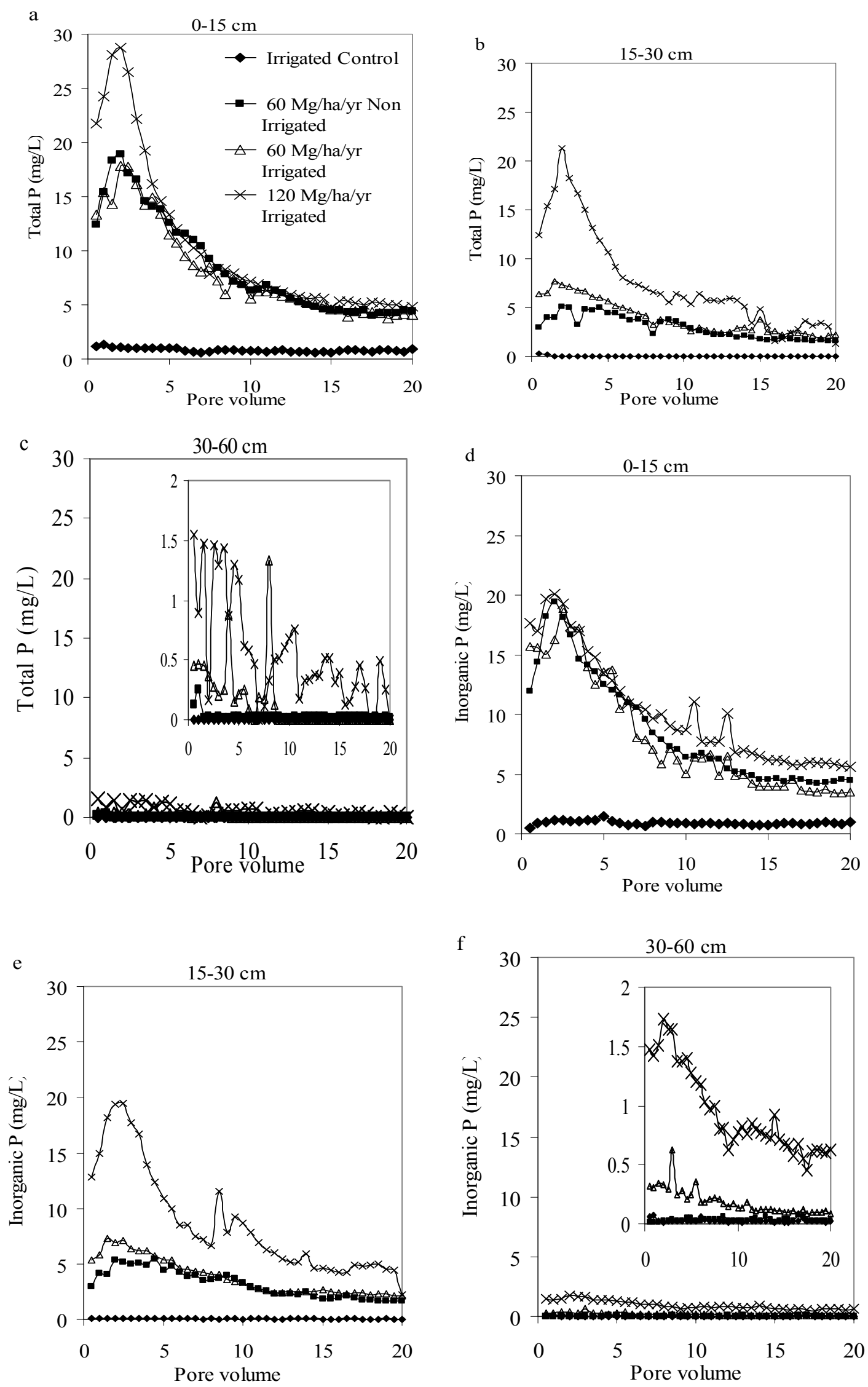

Figure 2. Impact of irrigation and rate of manure application on the advection of total $(a, b, c)$ and inorganic $\mathrm{P}(\mathrm{d}$, e, f) in the surface $0-15 \mathrm{~cm}$ soil and sub-surface $15-30 \mathrm{~cm}$ soil and $30-60 \mathrm{~cm}$ soil 

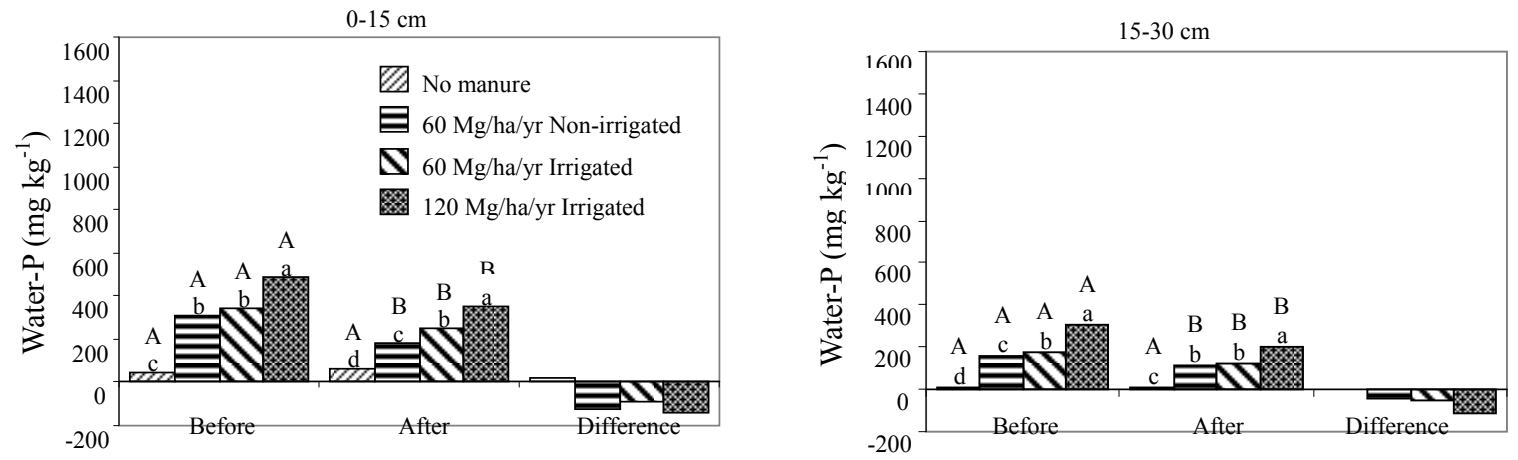

a

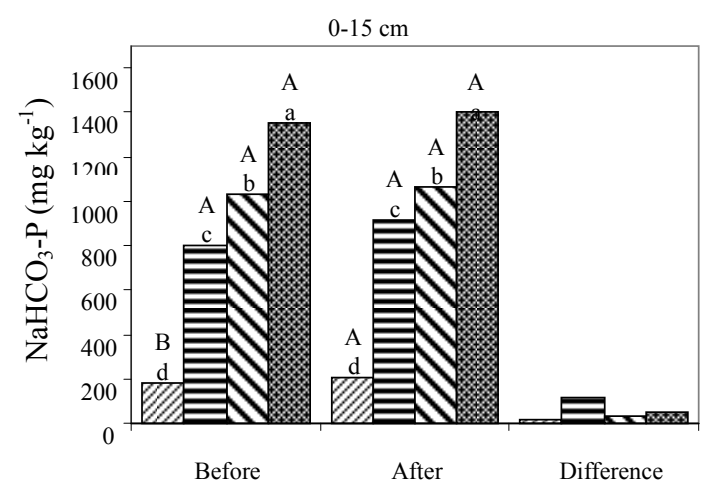

$\mathrm{b}$

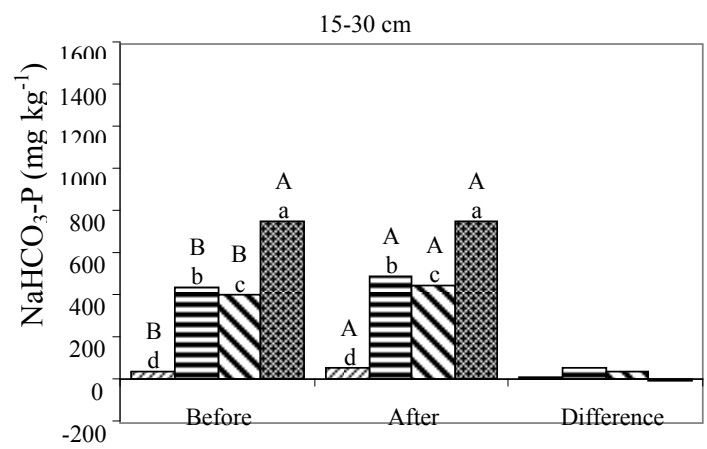

Figure 3. Changes in soil labile $\mathrm{P}$ before and after column leaching followed by air-drying: (a) water-P in surface 0-15 cm soil (b) water-P in sub-surface $15-30 \mathrm{~cm}$ soil (c) $\mathrm{NaHCO}_{3}-\mathrm{P}$ in surface $0-15 \mathrm{~cm}$ soil (d) $\mathrm{NaHCO}_{3}-\mathrm{P}$ in sub-surface $15-30 \mathrm{~cm}$ soil

(Negative extractable $\mathrm{P}$ concentration indicates resultant loss of $\mathrm{P}$ following column leaching;

Columns followed by the same lower case letter within a group were not significantly different, $p>0.05$;

Columns followed by the same upper case letter across the groups for the same treatment were not significantly different, $p>0.05$ ). 

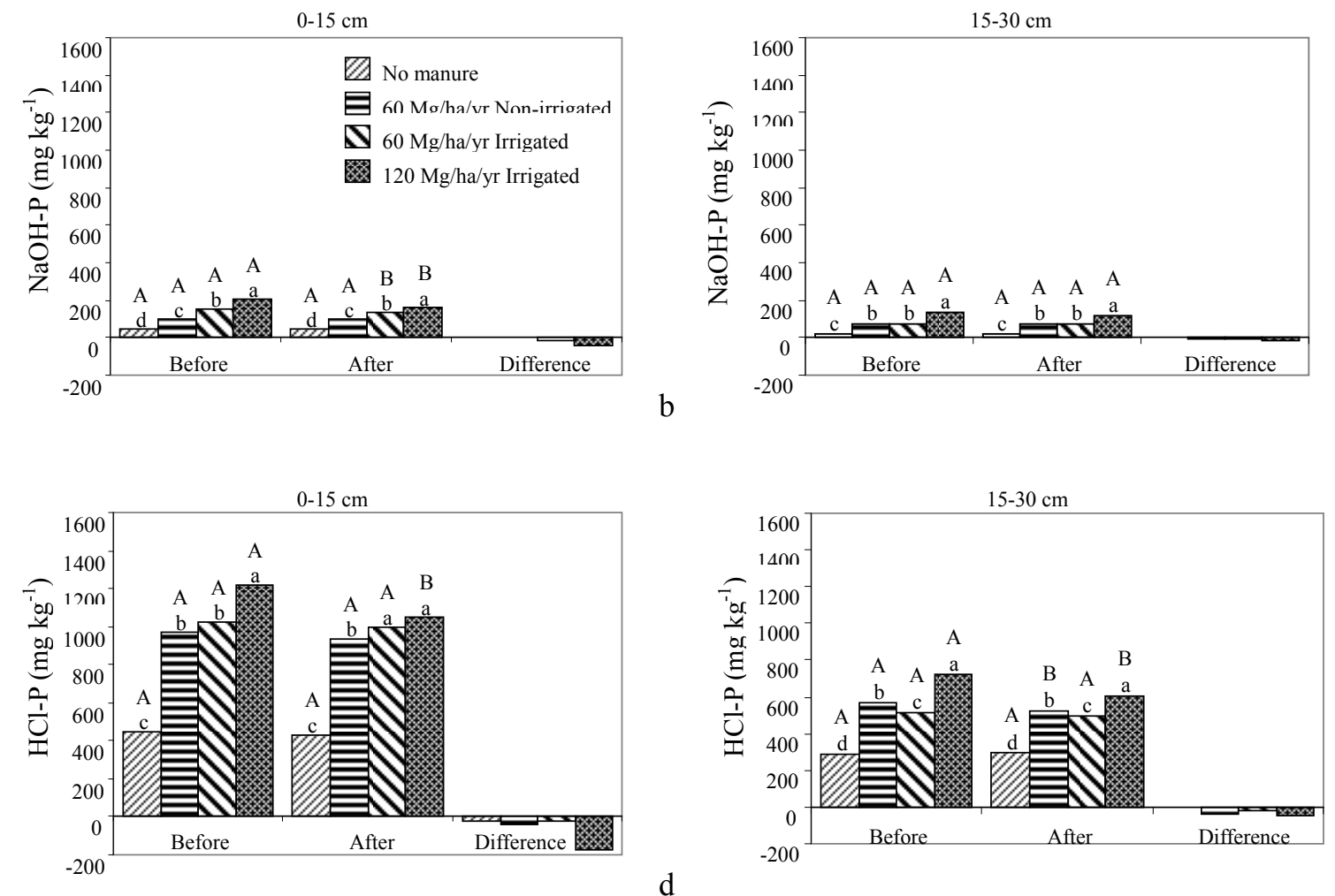

c
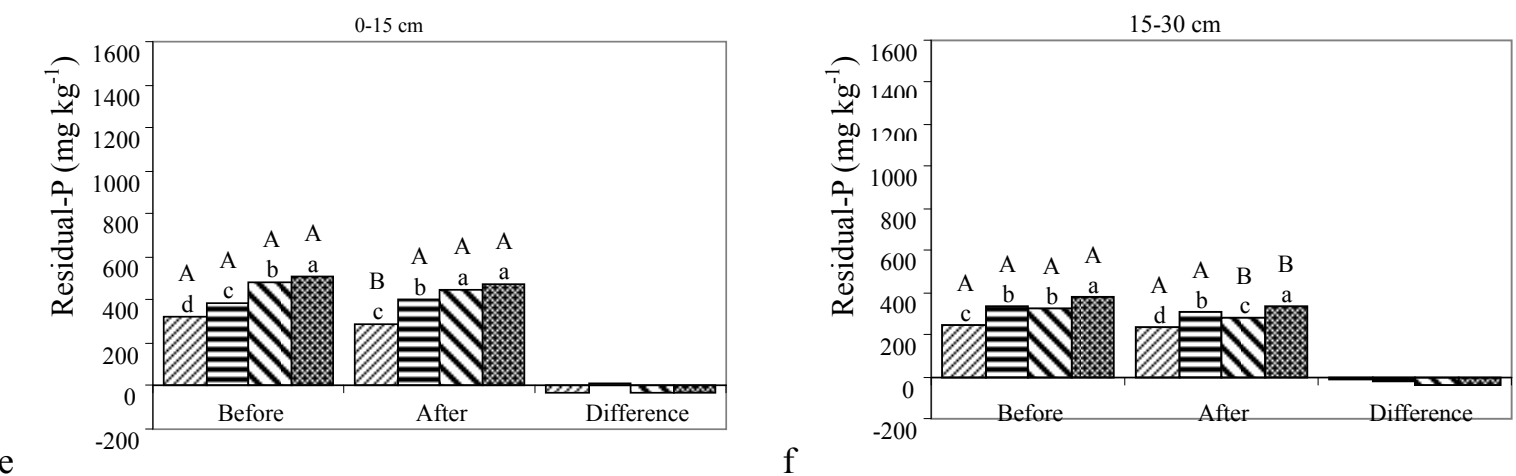

Figure 4. Changes in soil non-labile $P$ fractions before and after column leaching followed by air-drying. (a) $\mathrm{NaOH}-\mathrm{P}$ in surface $0-15 \mathrm{~cm}$ soil (b) $\mathrm{NaOH}-\mathrm{P}$ in sub-surface $15-30 \mathrm{~cm}$ soil (c) HCl-P in surface $0-15 \mathrm{~cm}$ soil (d) HCl-P in sub-surface 15-30 cm soil (e) residual-P in surface 0-15 cm soil (d) Residual-P in sub-surface 15-30 cm soil

(Negative extractable P concentration indicates resultant loss of P following column leaching;

Columns followed by the same lower case letter within a group were not significantly different, $p>0.05$;

Columns followed by the same upper case letter across the groups for the same treatment were not significantly different, $p>0.05$ ). 